\title{
Sebepojetí absolventů domácího vzdělávání a jejich spolužáků: pilotní studie
}

\section{Yvona Kosteleckáa ${ }^{a}, K^{2}$ teřina Machovcová ${ }^{\mathrm{b}}$, Andrea Beláňovác, Romana Štambergová ${ }^{d}$}

\author{
a Univerzita Karlova, Pedagogická fakulta, Ústav profesního rozvoje pracovníků ve školství \\ b Kateřina Machovcová, Univerzita Karlova, Pedagogická fakulta, Ústav profesního rozvoje \\ pracovníků ve školství \\ ${ }^{\mathrm{c}}$ Andrea Beláňová, Univerzita Karlova, Pedagogická fakulta, Ústav profesního rozvoje \\ pracovníků ve školství

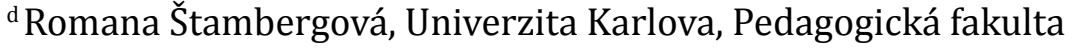

\section{Redakci zasláno 15. 2. 2018 / upravená verze obdržena 24. 6. 2018/}

k uveřejnění přijato 24. 6. 2018

\begin{abstract}
Abstrakt: Studie je první výzkumnou sondou do problematiky sebepojetí absolventů domácího vzdělávání. Jedná se o dílčí, ale velmi významné téma, kterému se v našich podmínkách ve vztahu k domácímu vzdělávání zatím nedostalo náležité pozornosti. Cílem studie je zjistit, jak děti s touto specifickou zkušeností samy sebe vnímají, a porovnat jejich výsledky se spolužáky, kteří domácím vzděláváním neprošli. První část textu je zaměřená na teoretická východiska, koncept sebepojetí a metodologii výzkumu, ve druhé části jsou prezentovány výsledky pilotního výzkumného šetření. Jedním z hlavních přínosů této pilotní studie je obrácení pozornosti $\mathrm{k}$ individualitě vzdělávaného, nikoli pouze vzdělávajícího, což je $\mathrm{v}$ případě studií zaměřených na domácí vzdělávání doposud převažující přístup, a ověrení, zda lze Dotazník sebepojetí Piers-Harris 2 považovat za vhodný nástroj pro realizaci obdobně zaměřených výzkumů.
\end{abstract}

Klíčová slova: domácí vzdělávání, sebepojetí, sociální vývoj, emoční vývoj, adaptace

Studie si klade za cíl učinit první pokus o porozumění sebepojetí dětí se zkušeností $\mathrm{s}$ individuálním (domácím) vzděláváním v českém vzdělávacím prostředí. Konkrétně se zaměřuje na absolventy tohoto způsobu vzdělávání, kteří se v současné době již účastní standardní školní docházky. Ve snaze prozkoumat, zda a případně jak se liší sebepojetí dětí, které v minulosti prošly domácím vzděláváním, od sebepojetí dětí vzdělávaných ve škole, jsme zrealizovaly pilotní studii založenou na aplikaci dotazníku sebepojetí Piers-Harris 2. Zjištění z tohoto šetření diskutujeme na základě relevantních dat zajištěných prostřednictvím kvalitativního šetření realizovaného https://doi.org/10.5817/PedOr2018-2-306 
v letech 2016-2017 formou (a) hloubkových rozhovorů s padesáti rodiči se zkušeností s domácím vzděláváním svých dětí, (b) ohniskových rozhovorů se šesti absolventy domácího vzdělávání a sedmi rodiči absolventů domácího vzdělávání a (c) longitudinálních pozorování ve čtyřech rodinách, které svoje děti vzdělávají tímto způsobem.

Předkládaný text reaguje na dva $\mathrm{v}$ odborné literatuře diskutované protichůdné názorové proudy týkající se domácího vzdělávání. Na jedné straně se objevují obavy z možných negativních dopadů domácího vzdělávání na dítě (viz např. Štech, 2003); na straně druhé existují studie, podle kterých doma vzdělávané děti disponují větší sebedůvěrou a mají lepší studijní výsledky (viz Medlin, 2013; Taylor, 1986, 1992). Podíváme-li se podrobněji na zformulované výhrady (Štech, 2003), pak nacházíme určité principiální obavy týkající se způsobů socializace těchto dětí. Podle Štecha (2003) mají primární socializace (v rodině) a sekundární socializace (ve škole) jinou funkci. Primární socializace silně ovlivňuje tu sekundární, zároveň v novém, školním, prostředí dochází k nové sebe-identifikaci dítěte v nových vztazích, $\mathrm{k}$ jeho emancipaci od rodiny - k přehodnocení rodinou vštípených hodnot, kdy může dojít $\mathrm{k}$ jejich posílení nebo proměně. Výhoda školy spočívá v tom, že se dítě musí učit vycházet s lidmi, které by si jinak do okruhu přátel samo nevybralo. Autor se obává možných negativních důsledků domácího vzdělávání, a to jak v rovině sociálních dovedností, které mohou být omezené vyrůstáním v určité sociální izolaci, tak i v rovině kognitivní (viz např́íklad problematika formalizovaného učení). Tyto výhrady se neomezují pouze na české prostředí. Medlin (2013) reaguje na některé z nich systematickou přehledovou studií různých aspektů socializace doma vzdělávaných dětí a shrnuje dosavadní výzkumně podložené výsledky studií zaměřených na sociální dovednosti, emoční inteligenci, morální a duchovní rozvoj nebo přechod do dospělosti. Na základě sebraných výsledků pak odpovídá na otázku „Získávají doma vzdělávané děti dovednosti, vzorce chování, hodnoty a motivace, které potřebují k tomu, aby fungovaly jako kompetentní členové společnosti?" jednoznačným ano.

Vzhledem k tomu, že v českém prostředí je domácí vzdělávání stále relativně novým fenoménem (legalizováno v roce 2005), který se vyvíjí a teprve postupně nachází své místo ve vzdělávacím systému, byla dosud v centru zájmu odborné veřejnosti spíše obecnější témata zaměřená na praxi domácího vzdělávání a její legalizaci (viz např́íklad Hájková, 2017; Hána, 2017; Jančaříková \& Jančař́k, 2017; Kašparová, 2015ab, 2017; Kostelecká, 2003, 2010, 2012, 
2014ab, 2017ab; Kostelecká et al., 2016; Mertin, 2003; Pražáková, 2012). Naši studii lze tedy $\mathrm{v}$ tomto ohledu považovat za ojedinělou sondu do problematiky sebepojetí dětí se zkušeností s domácím vzděláváním, nicméně s ohledem na charakter pilotáže je závěry možné chápat pouze jako dílčí východiska pro další výzkum.

$\mathrm{K}$ diagnostice sebepojetí jsme využily Dotazník pro děti a adolescenty Piers-Harris 2, který byl v zahraničí aplikován v řadě obdobných studií a na českou populaci standardizován v roce 2015. Použití dotazníkové metody klade těžiště studie do sféry subjektivní výpovědi daného žáka, což považujeme za klíčové zejména proto, že řada dosavadních studií se zaměřovala spíše na perspektivu rodičů či učitelů. Dotazník pro děti a adolescenty Piers-Harris 2 jsme dosud aplikovaly na malém vzorku populace domácích školáků a jejich spolužáků, abychom ověřily možnosti jeho dalšího použití $\mathrm{v}$ daném kontextu a navrhly př́ípadně propojení s dalšími vhodnými výzkumnými metodami. Tato data byla dále doplněna o zjištění z rozsáhlejší kvalitativně zaměřené studie domácího vzdělávání, realizované v letech 2016-2017.

\section{Problematika sebepojetí dětí v domácím vzdělávání}

Sebepojetí jedince, $\mathrm{v}$ anglosaské literatuře známé pod pojmem self-concept, je vícerozměrný konstrukt vztažený na porozumění chování a prožívání jednotlivce (Blatný, 2010). Ačkoliv se někdy pojem sebepojetí používá jako alternativní výraz k pojmům sebeúcta a sebereflexe (Piers \& Herzberg, 2002), v tomto textu budeme pracovat s pojetím podle Blatného (2010). O konceptu sebepojetí, tedy o postoji k sobě, at' už implicitním, nebo explicitním, lze uvažovat ve třech klíčových rovinách: (a) kognitivní, tedy o obsahu sebepojetí a jeho struktuře, (b) afektivní, tedy emociální vztah k sobě (sebehodnocení), (c) konativní, tedy o motivační funkci s vlivem na regulaci chování. Předpokládá se, že sebepojetí je v průběhu času relativně stabilní, protože jednotlivci mívají obecně tendenci udržovat si v čase konzistentní přesvědčení sami o sobě. Sebepojetí se utváří především v dětství prostřednictvím interakce s prostředím a skrze postoje a chování druhých (Kenny \& Vazquez, 2017). Sebepojetí lze chápat jako součást tzv. jáského systému/ sebesystému (self-system), který dynamicky propojuje Já jako poznávající, činný subjekt a Já jako objekt poznání a hodnocení sebe sama, tedy sebepojetí (Blatný, 2010). 
Vzhledem k tomu, že sebepojetí dítěte je považováno za klíčovou charakteristiku podmiňující jeho sociální a emocionální rozvoj (viz např́iklad Kenny \& Vazquez, 2017), je v některých případech používáno k detekci možných abnormalit ve vývoji dítěte. Například Taylor $(1986,1992)$ zjištoval sebepojetí 224 doma vzdělávaných dětí a naměřené hodnoty porovnával se sebepojetím amerických žáků a studentů vzdělávaných klasickým způsobem. Cílem bylo identifikovat, zda domácí vzdělávání poskytuje dostatečný prostor pro sociální a emoční rozvoj dítěte. Porovnání výsledků dětí v domácím vzdělávání s výsledky dětí vzdělávaných ve školách pak umožnilo odhalit specifika obou skupin. Závěry studií ukazují na statisticky významně pozitivnější sebepojetí žáků v domácím vzdělávání, a to ve všech subškálách Dotazníku PiersHarris. Polovina žáků v domácím vzdělávání dosahovala v celkovém skóre 91. percentilu a výše. Závěrem Taylor $(1986,1992)$ uvádí, že pokud je sebepojetí dítěte odrazem socializace, zdá se, že je jen málo domácích školáků sociálně deprivováno. Studie přinesla i řadu dalších zjištění, například bylo identifikováno, že sebepojetí respondentů bylo signifikantně negativnější $\mathrm{s}$ jejich rostoucím věkem a ročníkem vzdělávání. Faktory jako pohlaví, počet sourozenců, místo bydliště, předchozí zkušenosti se školní docházkou, věk při nástupu školní docházky, úroveň vzdělání vzdělavatelů nebo geografický region neměly signifikantní vliv na sebepojetí domácích školáků, pokud byly testovány nezávisle. Naopak vyšší socioekonomický status rodiny a vyšší počet domácích školáků $v$ rodině statisticky významně pozitivně ovlivňovaly sebepojetí dítěte ${ }^{1}$ (Taylor, 1986, 1992).

$\mathrm{V}$ tomto textu, $\mathrm{v}$ určité návaznosti na výše uvedené studie, představujeme výsledky prvního pokusu o poznání sebepojetí absolventů domácího vzdělávání v České republice. Naše data porovnáme s Taylorovou $(1986,1992)$ studií, která zjištovala sebepojetí dětí v domácím vzdělávání na přelomu 80. a 90. let 20. století ve Spojených státech amerických. Zaměřujeme se však na zjištování sebepojetí u českých dětí, které prošly domácím vzděláváním, ale v současné době jsou již vzdělávány ve škole. Jejich sebepojetí porovnáme se sebepojetím jejich spolužáků. Realizace této studie je možná díky tomu, že v roce 2015 vydal kolektiv autorů pod vedením Radka Obereignerů v nakladatelství Hogrefe - Testcentrum první českou verzi dotazníku s názvem

Model, který měl nejlepší schopnost vysvětlit úroveň sebepojetí domácích školáků, vysvětloval $12 \%$ variability a uplatňovaly se v něm následující nezávislé proměnné: skóre $\mathrm{v}$ testech, počet let $\mathrm{v}$ domácím vzdělávání, počet doma vzdělávaných dětí v rodině a věk zahájení školní docházky (Taylor, 1986). 
Dotazník sebepojetí dětí a adolescentů Piers-Harris 2. Anglická verze tohoto dotazníku byla využita k základní identifikaci sebepojetí respondentů i ve výše zmiňované studii Taylora (1986).

V posledních desetiletích sledujeme v České republice i ve světě, především pak v anglosaských zemích, renesanci domácího vzdělávání (dále DV), v němž zodpovědnost za vzdělávání přebírají rodiče a děti jsou primárně vzdělávány mimo standardní vzdělávací instituce (Taylor, 1986). Tento staronový fenomén s sebou přináší řadu otázek, na které je potřeba hledat odpovědi. Jednou z nejčastějších je, zda domácí vzdělávání dokáže dítěti nabídnout dostatečný prostor pro jeho žádoucí sociální vývoj (viz např́iklad Medlin, 2013; Ray, 2013; Romanowski \& Pham, 2006). Jak již bylo uvedeno výše, Taylor (1986, 1992) využil jako základ pro identifikaci sociálně-emočního vývoje dětí v domácím vzdělávání Dotazník sebepojetí Piers-Harris 2. I když je tento dotazník považován za důležitý nástroj pro identifikaci sebepojetí jedince, není schopen sám o sobě poskytnout úplný a celistvý pohled (Obereignerů et al., 2015), protože komplexní zhodnocení sebepojetí by vyžadovalo ještě další zdroje informací, které lze získat například za použití dalších psychodiagnostických metod, rozhovorem, analýzou prospěchu, sociometrickými metodami atd. $V$ našem případě dotazník slouží pouze jako první nástroj a budeme ověřovat jeho možnosti využití $\mathrm{v}$ dalším zkoumání námi sledované problematiky. Z tohoto důvodu na vybraných místech konfrontujeme předběžné výsledky s poznatky z našich kvalitativních šetření (2016-2017).

\section{Metodologie výzkumu a představení výzkumného instrumentu}

Dotazník sebepojetí dětí Piers-Harris, v anglosaské literatuře znám pod pojmem Piers-Harris Children's Self-concept Scale (PHCSCS), vytvořili již na počátku 60. let Ellen V. Piers a Dale B. Harris. Dotazník sebepojetí dětí se týká sebevnímání dítěte ve vztahu k důležitým aspektům života (Piers \& Herzberg, 2002). V průběhu času dotazník prodělal několik významných změn (viz například Piers, 1984, 1994; Piers \& Herzberg, 2002). Na rozdíl od předchozích vzešla americká verze dotazníku PHCSCS2 z reprezentativních normovaných dat. Normy vznikly z testování několika stovek žáků ve věku 7-18 let napříč celými Spojenými státy, vzorek odpovídal etnickému složení populace tak, jak bylo zaznamenáno ve sčítání lidu v roce 2001 (Obereignerů et al., 2015). Již zmíněná česká verze dotazníku s podtitulem Jak vnímám sám/sama sebe byla standardizována na vzorku 2600 žáků (Obereignerů et al., 2015). 
Moderní verze dotazníku má 60 položek v šesti subškálách ${ }^{2}$ (viz Obereignerů et al., 2015): Přizpůsobivost BEH (14 položek), Intelektové a školní postavení INT (16 položek), Fyzický zjev a vlastnosti PHY (11 položek), Nepodléhání úzkosti FRE (14 položek), Popularita POP (12 položek), Štěstí a spokojenost HAP (10 položek). Položky testu jsou dichotomické, typu ano/ne. Pokrývají různé aspekty sebepojetí dětí prostřednictvím otázek a výroků typu: Jsem dobrý člověk, Nesnáším školu apod. Subškála Přizpưsobivost, někdy též označovaná jako Chování, měří, zda si jedinec připouští, nebo zda popírá své problematické chování. Děti, které v této subškále dosahují nadprůměrných skóre, se vnímají jako dobře vychované. Subškála Intelektové a školní postavení identifikuje, jak se jedinec vnímá v oblasti intelektuálních a školních povinností a zjištujuje také spokojenost jedince se školou a jeho ambice. Jedinci $\mathrm{s}$ nadprůměrným skóre $\mathrm{v}$ této subškále se cítí dobře $\mathrm{v}$ oblasti intelektových schopností a věří svým školním výkonům. Subškála Fyzický zjev a vlastnosti mapuje, jak jedinec hodnotí nejen svůj zjev, ale také svoje vlastnosti, především vůdčí dovednosti. Jedinci, kteří dosahují v této subškále nadprůměrných skóre, se vnímají jako fyzicky atraktivní, inteligentní a schopní vedení. Subškála Nepodléhání úzkosti měří úzkost a dysforickou náladu. Jedinci s nadprůměrným skóre méně často pocitují negativní emoce jako smutek, nervozitu, obavy apod. Subškála Popularita kvantifikuje sociální fungování jedinců, respektive vnímanou popularitu, schopnost navazovat vztahy apod. Jedinci, kteří dosahují nadprůměrných skóre, se cítí dobře v kolektivu ostatních jedinců, cítí svoji oblibu a prožívají v této oblasti spokojenost. Subškála Štěstí a spokojenost měří míru prožívaného štěstí a spokojenosti. Jedinci s nadprůměrným skóre zažívají pocity pohody, naopak jedinci s nízkým skóre udávají pocity nespokojenosti se sebou samými. Můžou být kritičtí ke svému vzhledu, ke schopnosti komunikovat s ostatními či ke svým vlastnostem.

Česká verze dotazníku je určena dětem a mládeži ve věku 9-18 let. Vzhledem $\mathrm{k}$ tomu, že je potřeba, aby odpovědi odrážely to, co respondenti opravdu cítí, je autory české verze doporučováno, aby byl dotazník administrován individuálně, případně $\mathrm{v}$ malých skupinách, aby měl tazatel možnost $s$ respondenty navázat vztah a představit jim co nejlépe účel, ke kterému dotazník slouží. $V$ našem př́padě byly dotazníky respondentům zadávány učitelem, který s dětmi dlouhodobě pracuje. Učiteli byla prezentována všechna pravidla a zásady správného zadávání dotazníku včetně účelu testování.

\footnotetext{
Jednotlivé subškály byly vytvořeny na základě faktorové analýzy (Obereignerů et al., 2015).
} 
Dotazník byl zadáván jednou z doporučených forem: „papír-tužka“. Získaná data byla zakódována, vyčištěna a podrobena analýze.

\subsection{Základní charakteristiky vzorku}

Šetření prostřednictvím české verze Dotazníku sebepojetí dětí Piers-Harris 2 probíhalo v roce 2017 na víceletém gymnáziu. Do šetření se zapojily čtyři třídy gymnázia, které měly alespoň jednoho absolventa domácího vzdělávání viz tabulka 1. Jednalo se o primu, tercii, kvartu a septimu. Nejvíce participantů výzkumu bylo rekrutováno z kvarty, nejméně z primy, nicméně zapojení respondentů $\mathrm{z}$ jednotlivých ročníků bylo víceméně vyrovnané. Celkově se šetření zúčastnilo 81 respondentů, viz tabulka 1.

Tabulka 1

Respondenti dle tř́ld

\begin{tabular}{lcccc}
\hline & Počet & Procenta & Validní procenta & $\begin{array}{c}\text { Kumulativní } \\
\text { procenta }\end{array}$ \\
\hline Prima & 19 & 23,5 & 23,5 & 23,5 \\
Tercie & 17 & 21,0 & 21,0 & 44,5 \\
Kvarta & 25 & 30,9 & 30,9 & 75,4 \\
Septima & 20 & 24,7 & 24,7 & 100,0 \\
Celkem & 81 & 100,0 & 100,0 & \\
\hline
\end{tabular}

Pozn.: Data z vlastního šetření.

Po vyhodnocení validity výsledků PHCSCS2 u každého konkrétního jedince $\mathrm{s}$ důrazem na sledování možnosti zkreslení výsledkư ${ }^{4}$ ze strany respondentů

3 Absolvent domácího vzdělávání studující septimu se nakonec rozhodl, že se do šetření nezapojí.

4 Jak uvádí Obereignerů a kol. (2015), v PHCSCS2 děti poměrně běžně zkreslují své odpovědi směrem $k$ vyšší konvenčnosti či sociálním požadavkům. Tato zkreslení však nemusí být úmyslná, mohou být pouze odrazem určitého zmatku ve vlastních pocitech. Naopak negativní zkreslení se podle Obereignerů a kol. (2015) v PHCSCS2 u dětí vyskytuje poměrně vzácně, protože dětem zkreslení v tomto směru většinou nepřináší zisky. Nízké hodnoty v PHCSCS2 u dětí tedy zpravidla indikují skutečně nízkou sebeúctu. 
nadsazováním, předpojatostí ${ }^{5}$, náhodnými odpověd'mi ${ }^{6}$ apod..$^{7}$ byly nakonec do následných analýz zařazeny pouze výsledky dotazníků, které splňovaly požadovaným způsobem podmínky pro vyhodnocení doporučované autory. Nakonec bylo do analýzy zařazeno 71 dotazníků původních 81 respondentů. Z tohoto počtu bylo šest studentů se zkušeností z domácího vzdělávání (dále absolventů DV) ${ }^{8}$ a 65 spolužáků, viz tabulky 2 .

Tabulka 2

Respondenti splňující všechny podmínky pro zařazení do analýzy celkem (dělení dle tříd, pohlaví a vzdělávací historie)

\begin{tabular}{lccc}
\hline & $\begin{array}{c}\text { Spolužáci absolventů DV } \\
\text { (z toho počet dívek) }\end{array}$ & $\begin{array}{c}\text { Absolventi DV } \\
\text { (z toho počet dívek) }\end{array}$ & $\begin{array}{c}\text { Celkem } \\
\text { (z toho počet dívek) }\end{array}$ \\
\hline Prima & $15(5)$ & $3(0)$ & $18(5)$ \\
Tercie & $13(4)$ & $2(0)$ & $15(4)$ \\
Kvarta & $20(8)$ & $1(1)$ & $21(9)$ \\
Septima & $17(5)$ & $0^{9}$ & $17(5)$ \\
Celkem & $65(22)$ & $6(1)$ & $71(23)$ \\
\hline
\end{tabular}

Pozn.: Data z vlastního šetření.

5 Předpojatost Obereignerů a kol. (2015) definují jako tendenci vyjadřovat souhlas či nesouhlas $\mathrm{s}$ výrokem, a to bez ohledu na jeho obsah. $\mathrm{V}$ př́padě pozitivní předpojatosti má dítě tendenci nezávisle na znění výroku odpovídat ano, při negativní předpojatosti ne. Při vyhodnocování dotazníku se pracuje s Indexem predpojatosti (RES). Pokud je hodnota RES větší nebo rovna 40, případně 17 a nižší, nedoporučuje se dotazník interpretovat, za určitých okolností a při dodržení určitých pravidel je však možné dotazník readministrovat (Obereignerůet al., 2015).

6 Za účelem odhalení náhodných odpovědí byl vytvořen Index inkonzistentních odpovědí (INC). Čím vyšší hodnota indexu, tím vyšší počet náhodných odpovědí. Pokud je hrubé skóre INC vyšší než 4 , je potřeba předpokládat, že byly odpovědi minimálně na některé dotazy náhodné.

7 Bližší informace viz Obereignerů a kol. (2015).

8 Respondenti $\mathrm{z}$ řad absolventů domácího vzdělávání byli doma vzděláváni na úrovni 1. stupně ZŠ, a to v rozmezí 1-5 let. Za absolventa domácího vzdělávání zde považujeme jedince se zkušeností s DV, který již aktuálně není v DV, a to nezávisle na době strávené tímto způsobem vzdělávání.

9 Jak již bylo zmíněno, absolvent domácího vzdělávání ze septimy se nezapojil do realizovaného šetření. 


\subsection{Základní deskriptivní analýza}

V následující části textu analyzujeme průměr Hrubých skóre sebepojetí, kterého respondenti v české verzi dotazníku PHCSCS2 dosáhli a který zahrnuje Celkové skóre (TOT) v jednotlivých subškálách, ${ }^{10}$ a to v závislosti na tom, zda byli v minulosti respondenti v domácím vzdělávání, či nikoli. Vzhledem k tomu, že Celkové skóre TOT i skóre jednotlivých subškál (BEH, INT, PHY, FRE, POP, HAP) vznikly převodem normalizovaných hrubých skóre na T-skóre ${ }^{11}$, které mají průměr 50 a standardní odchylku 10, to znamená, že získána hodnota T-skóre koresponduje u všech škál dotazníku s percentilovým pořadím a lze tak jednoduše porovnávat rozdíly mezi jednotlivými subškálami dotazníku i identifikovat postavení jedince vzhledem k průměru standardizovaného souboru (Obereignerů a kol., 2015).

Tabulka 3 ukazuje průměry Hrubých skóre sebepojetí (T-skóre) spolužáků absolventů DV a absolventů DV. Přitom obecně platí, že čím vyšší hodnota, tím pozitivnější sebepojetí, tím vyšší sebehodnocení, a naopak nízké hodnoty skóre mohou ukazovat na obecnější problémy v sebepojetí, a tedy i nižší sebehodnocení (Obereignerů et al., 2015). Z tabulky vyplývá, že průměry Hrubých skóre sebepojetí spolužáků absolventů DV se nachází v průměru v porovnání s normativním souborem. Průměr Celkového skóre spolužáků absolventů DV se nachází téměř uprostřed průměru normativního souboru, který interpretuje průměr jako dosažení hodnot 45-55 T. Obdobná situace je i v př́ípadě jednotlivých subškál, pro které je průměrná normativní hodnota definována také v rozmezí 45-55 T.

Mírně odlišných výsledků dosáhli v tomto ohledu absolventi DV, jejichž průměr Celkových skóre se nachází v pásmu nižšího průměru, který je definován hodnotami 40-44 T. Obdobná situace je i u jednotlivých subškál, kdy absolventi DV dosahují ve třech subškálach (Fyzický zjev a vlastnosti - PHY, Popularita - POP, Štěstí a spokojenost - HAP) výsledků v pásmu mírného podprůměru (40-44 T). Průměr skóre zbylých tří subškál (Přizpůsobivost $\mathrm{BEH}$, Intelektové a školní postavení - INT, Nepodléhání úzkosti - FRE) se nachází, obdobně jako u jejich spolužáků, v pásmu průměru. Nicméně ve všech sledovaných kategoriích je hodnota průměru výsledků skupiny absolventů DV mírně nižší než hodnota průměru u jejich spolužáků. Nejmenší rozdíly

10 Bližší informace viz Obereignerů a kol. (2015).

11 Normalizované T-skóre je primárním standardním skóre dotazníku PHCSCS2. Byl vytvořen tak, že původní distribuce hrubých skóre byla převedena tak, aby se blížila normálnímu rozložení (Obereignerů et al., 2015). 
mezi oběma skupinami byly zaznamenány u subškály Intelektové a školní postavení - INT a subškály Přizpůsobivost - BEH. Zdá se tedy, že v těchto oblastech si skupina absolventů DV nejvíc věřila. Naopak největší rozdíly mezi oběma skupinami byly shledány u subškály Fyzický zjev a vlastnosti - PHY, následované subškálou Štěstí a spokojenost - HAP. Zdá se, že v těchto oblastech si námi sledovaná skupina absolventů domácího vzdělávání věřila nejméně. Tato zjištění není v žádném případě možné zevšeobecňovat na všechny absolventy DV, protože skupina absolventů DV zkoumaná v našem případě čítá pouze šest jedinců.

Tabulka 3

Průměry Hrubých skóre sebepojetí (TOT, BEH, INT, PHY, FRE, POP, HAP)

\begin{tabular}{ccccccccc}
\hline \multicolumn{2}{c}{ Sledované skupiny } & TOT & BEH & INT & PHY & FRE & POP & HAP \\
\hline \multirow{2}{*}{ Spolužáci } & Průměr & 49,2 & 47,2 & 51,0 & 51,0 & 51,1 & 47,1 & 48,1 \\
absolventů DV & $\mathrm{N}$ & 65 & 65 & 65 & 65 & 65 & 65 & 65 \\
& $\mathrm{SD}$ & 10,3 & 12,1 & 11,0 & 10,0 & 9,3 & 9,3 & 9,5 \\
\hline \multirow{4}{*}{ Absolventi DV } & Průměr & 44,3 & 45,5 & 49,3 & 43,2 & 49,2 & 41,2 & 41,3 \\
& $\mathrm{~N}$ & 6 & 6 & 6 & 6 & 6 & 6 & 6 \\
& $\mathrm{SD}$ & 12,0 & 11,3 & 13,0 & 7,7 & 14,0 & 10,8 & 12,5 \\
\hline \multirow{3}{*}{ Celkem } & Průměr & 48,8 & 47,1 & 50,8 & 50,2 & 51,0 & 46,6 & 47,5 \\
& $\mathrm{~N}$ & 71 & 71 & 71 & 71 & 71 & 71 & 71 \\
& $\mathrm{SD}$ & 10,5 & 12,0 & 11,0 & 10,0 & 9,7 & 9,5 & 9,9 \\
\hline
\end{tabular}

Pozn.: Data z vlastního šetření. SD značí směrodatnou odchylku, N počet případů.

V následující části studie prezentujeme výsledky, kterých dosáhli jednotliví respondenti v Celkových skóre (TOT) v dotazníku PHCSCS2. Celkové skóre je velmi důležitým ukazatelem, je považováno za nejprozkoumanější a nejspolehlivější měřítko PHCSCS2 (Obereignerů et al., 2015). Výsledky dotazovaných dětí budeme interpretovat v porovnání s normativním souborem jako: výrazný nadprůměr, nadprůměr, vyšší průměr, nižší průměr, podprůměr a výrazný podprůměr, a to postupně pro obě námi sledované skupiny. Tabulka 4 ukazuje zařazení spolužáků absolventů DV do výše zmíněných kategorií dle výsledků v Celkových skóre, kterých dosáhli. Z tabulky vyplývá, že v dotazníku dosáhlo více než 85 \% respondentů, tj. 56 z 65 respondentů, velmi dobrých a dobrých výsledků: šest respondentů se nachází v oblasti výrazného nadprüměru, 12 respondentů v oblasti nadprůměru a výsledky 32 respondentů byly ve vyšším průměru. Dalších šest respondentů se nacházelo v oblasti nižšího průměru. Navzdory těmto potenciálně pozitivním zjištěním 
byli identifikováni čtyři respondenti, jejichž výsledky nebyly tak uspokojivé a nacházely se v oblasti podprůměru, což by mohlo indikovat možné vážné pochybnosti o vlastní hodnotě. Navíc bylo identifikováno dalších pět respondentů (tř̌i dívky a dva chlapci), kteří se nacházeli v pásmu výrazného podprůměru, což by mohlo signalizovat možné problémy v oblasti sebepojetí a bylo by vhodné dále zjištovat okolnosti jejich osobní situace.

Tabulka 4

Celková skóre v dotazníku PHCSCS2 u spolužáků absolventů DV dle tříd a kategorií: výrazný nadprůměr, nadprůměr, vyšší průměr, nižší průměr, podprůměr a výrazný podprůmèr

\begin{tabular}{|c|c|c|c|c|c|c|}
\hline & & Prima & Tercie & Kvarta & Septima & Celkem \\
\hline \multirow{3}{*}{$\begin{array}{c}\text { Výrazný } \\
\text { podprůměr }\end{array}$} & $\mathrm{N}$ & 0 & 0 & 3 & 2 & 5 \\
\hline & Řádková \% & $0,0 \%$ & $0,0 \%$ & $60,0 \%$ & $40,0 \%$ & $100,0 \%$ \\
\hline & Sloupcová \% & $0,0 \%$ & $0,0 \%$ & $15,0 \%$ & $11,8 \%$ & $7,7 \%$ \\
\hline \multirow{3}{*}{ Podprůměr } & $\mathrm{N}$ & 1 & 0 & 2 & 1 & 4 \\
\hline & Řádková \% & $25,0 \%$ & $0,0 \%$ & $50,0 \%$ & $25,0 \%$ & $100,0 \%$ \\
\hline & Sloupcová \% & $6,7 \%$ & $0,0 \%$ & $10,0 \%$ & $5,9 \%$ & $6,2 \%$ \\
\hline \multirow{3}{*}{ Nižší průměr } & $\mathrm{N}$ & 1 & 2 & 1 & 2 & 6 \\
\hline & Řádková \% & $16,7 \%$ & $33,3 \%$ & $16,7 \%$ & $33,3 \%$ & $100,0 \%$ \\
\hline & Sloupcová \% & $6,7 \%$ & $15,4 \%$ & $5,0 \%$ & $11,8 \%$ & $9,2 \%$ \\
\hline \multirow{3}{*}{ Vyšší průměr } & $\mathrm{N}$ & 8 & 7 & 8 & 9 & 32 \\
\hline & Řádková \% & $25,0 \%$ & $21,9 \%$ & $25,0 \%$ & $28,1 \%$ & $100,0 \%$ \\
\hline & Sloupcová \% & $53,3 \%$ & $53,8 \%$ & $40,0 \%$ & $52,9 \%$ & $49,2 \%$ \\
\hline \multirow{3}{*}{ Nadprůměr } & $\mathrm{N}$ & 4 & 4 & 2 & 2 & 12 \\
\hline & Řádková \% & $33,3 \%$ & $33,3 \%$ & $16,7 \%$ & $16,7 \%$ & $100,0 \%$ \\
\hline & Sloupcová \% & $26,7 \%$ & $30,8 \%$ & $10,0 \%$ & $11,8 \%$ & $18,5 \%$ \\
\hline \multirow{3}{*}{$\begin{array}{c}\text { Výrazný } \\
\text { nadprůměr }\end{array}$} & $\mathrm{N}$ & 1 & 0 & 4 & 1 & 6 \\
\hline & Řádková \% & $16,7 \%$ & $0,0 \%$ & $66,7 \%$ & $16,7 \%$ & $100,0 \%$ \\
\hline & Sloupcová \% & $6,7 \%$ & $0,0 \%$ & $20,0 \%$ & $5,9 \%$ & $9,2 \%$ \\
\hline \multirow{3}{*}{ Celkem } & $\mathrm{N}$ & 15 & 13 & 20 & 17 & 65 \\
\hline & Řádková \% & $20,0 \%$ & $30,8 \%$ & $26,2 \%$ & $100,0 \%$ & \\
\hline & Sloupcová \% & $100,0 \%$ & $100,0 \%$ & $100,0 \%$ & $100,0 \%$ & \\
\hline
\end{tabular}

Pozn.: Data z vlastního šetření.

Na rozdíl od skupiny spolužáků absolventů DV se žádný absolvent domácího vzdělávání nenachází v kategorii výrazného podprůměru, která indikuje 
jedince s možnými poruchami nálad či chování. Tři absolventi domácího vzdělávání, se nicméně nacházejí v pásmu podprůměru. Může se tedy jednat o jedince s vážnými pochybnostmi o sobě samých. Jeden absolvent domácího vzdělávání, se nachází v pásmu průměru a dva absolventi domácího vzdělávání, se nacházejí v pásmu vyššího prüměru. Námi sledovaní absolventi domácího vzdělávání se nenacházeli v odlehlejších kategoriích výrazného nadprůměru, nadprůměru a výrazného podprůměru, na rozdíl od skupiny jejich spolužáků.

Tabulka 5 zobrazuje průměry Hrubých skóre sebepojetí spolužáků absolventů domácích školáků dle jednotlivých tříd, respektive ročníků studia. Z tabulky vyplývá, že se hodnoty Celkových skóre i skóre dosažených v jednotlivých subškálách mají tendenci se vzrůstajícím ročníkem studia mírně zhoršovat. Nejmarkantnější a statisticky významný rozdíl na 99\% hladině pravděpodobnosti je patrný u subškály Štěstí a spokojenost - HAP. Žáci nižších ročníků vyjadřují vyšší míru uspokojení v této oblasti.

Tabulka 5

Průměry hrubých skóre sebepojetí spolužáků domácích školáků dle jednotlivých tř́d/ročníků studia

\begin{tabular}{ccccccccc}
\hline & Třida & TOT & BEH & INT & PHY & FRE & POP & HAP \\
\hline \multirow{4}{*}{ Prima } & Průměr & 51,6 & 51,1 & 50,2 & 50,4 & 54,5 & 49,0 & 52,1 \\
& $\mathrm{~N}$ & 15 & 15 & 15 & 15 & 15 & 15 & 15 \\
& $\mathrm{SD}$ & 6,7 & 11,3 & 10,7 & 9,8 & 7,2 & 8,0 & 6,1 \\
\hline \multirow{4}{*}{ Tercie } & Průměr & 51,1 & 47,0 & 51,5 & 53,6 & 51,9 & 47,9 & 54,1 \\
& $\mathrm{~N}$ & 13 & 13 & 13 & 13 & 13 & 13 & 13 \\
& $\mathrm{SD}$ & 4,9 & 11,2 & 7,6 & 6,0 & 8,0 & 7,1 & 3,7 \\
\hline \multirow{4}{*}{ Kvarta } & Průměr & 47,6 & 45,2 & 50,0 & 50,3 & 50,8 & 47,3 & 44,7 \\
& $\mathrm{~N}$ & 20 & 20 & 20 & 20 & 20 & 20 & 20 \\
& $\mathrm{SD}$ & 13,6 & 14,4 & 13,3 & 12,7 & 11,4 & 10,2 & 11,8 \\
\hline \multirow{5}{*}{ Septima } & Průměr & 47,4 & 46,3 & 52,3 & 49,8 & 48,1 & 44,6 & 44,1 \\
& $\mathrm{~N}$ & 17 & 17 & 17 & 17 & 17 & 17 & 17 \\
& $\mathrm{SD}$ & 11,5 & 10,7 & 11,2 & 9,5 & 8,9 & 10,0 & 8,9 \\
\hline \multirow{5}{*}{ Celkem } & Průměr & 49,2 & 47,2 & 51,0 & 50,9 & 51,1 & 47,1 & 48,1 \\
& $\mathrm{~N}$ & 65 & 65 & 65 & 65 & 65 & 65 & 65 \\
& $\mathrm{SD}$ & 10,3 & 12,1 & 11,0 & 10,0 & 9,3 & 9,3 & 9,5 \\
\hline
\end{tabular}

Pozn.: Data z vlastního šetření. SD značí směrodatnou odchylku. 
Předposlední charakteristikou, kterou budeme sledovat v této kapitole, je vztah našich respondentů ke škole, respektive jejich reakce na výrok Nesnáším školu. Odpovědi na tuto otázku nám mohou pomoci identifkovat, zda děti se zkušeností s domácím vzděláváním mají odlišný vztah ke škole než děti bez této zkušenosti. S tímto výrokem souhlasila pouze třetina absolventů DV, tj. pouze dva ze šesti respondentů z řad absolventů DV deklarovali, že nesnáší školu. Toto zjištění je v určitém ohledu pozitivní, protože ve standardizačním souboru odpovědělo kladně na tento výrok přibližně $43 \%$ respondentů (Obereignerů et al., 2015). Vzhledem k počtu respondentů nicméně není možné tento výsledek zobecňovat. I když jsou odpovědi absolventů DV na tuto otázku relativně pozitivní, odpovědi jejich spolužáků jsou ještě pozitivnější, pouze méně než $16 \%$ spolužáků absolventů DV souhlasilo s výrokem, že nesnáší školu. Bližší pohled na data nám navíc ukazuje, že v tomto ohledu nelze najít významnou souvislost mezi ročníkem studia a vztahem ke škole, pouze v kvartě lze identifikovat více jedinců než v ostatních třech třídách, kteří deklarují, že nesnášejí školu.

Poslední sledovanou charakteristikou je, v jaké míře respondenti souhlasí s výrokem Jsem dobrý člověk. Odpověd' na tento výrok má, na rozdíl od předchozího výroku, vysokou interpretační hodnotu, protože záporně odpovědělo na tento výrok pouze $8,7 \%$ participantů standardizačního souboru (Obereignerů et al., 2015), což v praxi znamená, že pouze velmi malé procento respondentů nesouhlasilo s tvrzením, že je dobrým člověkem. Jedincům, kteří na tuto otázku odpověděli záporně, by měla být věnována pozornost a měly by o nich být zjištovány další doplňující vysvětlující informace. Respondenti obou námi sledovaných skupin reagovali na tento výrok záporně v mírně vyšším procentu než participanti zmíněného standardizačního souboru - konkrétně $17 \%$ absolventů DV, což v praxi znamená, že jeden domácí školák ze šesti odpověděl na otázku Jsem dobrý člověk záporně. Spolužáci absolventů DV reagovali na zmíněný výrok dokonce o něco negativněji, $19 \%$ respondentů této skupiny nesouhlasilo s tímto výrokem. Zdá se, že v tomto ohledu jsou naši respondenti k sobě kritičtější a hodnotí se negativněji než participanti standardizačního souboru. K interpretaci bychom nicméně potřebovaly zjistit další možné intervenující proměnné.

\subsection{Výsledky žáků se zkušeností s domácím vzděláváním}

$\mathrm{V}$ této části zaměřujeme pozornost na absolventy DV. Vzhledem k nízkému počtu absolventů domácího vzdělávání v námi sledovaném souboru 
respondentů jsme se rozhodly data doplnit o případové mini-studie jednotlivých žáků, které mohou pomoci dokreslit základní informace, jež jsme získaly prostřednictvím deskriptivních analýz kvantitativních dat prezentovaných $\mathrm{v}$ předchozích částech textu. Př́́padové mini-studie jednotlivých respondentů, absolventů domácího vzdělávání, uvádíme v abecedním pořadí dle jejich přezdívek a konfrontujeme s vybranými poznatky z kvalitativních dat získaných během několika let výzkumu.

\section{Erich}

Erichovo Celkové skóre (TOT) se nachází v rámci průměru. $\mathrm{Z}$ dat uvedených $\mathrm{v}$ tabulce 6 a vizualizovaných $\mathrm{v}$ obrázku 1 lze u Ericha identifikovat relativně větší rozdíly mezi jednotlivými subškálami. Zjišt’ujeme, že se Erich cítí nejméně jistý v oblasti Fyzického zjevu a vlastností (PHY) a v oblasti Popularity (POP) a Přizpůsobivosti (BEH). V těchto oblastech se Erich nachází v nižším průměru, což znamená, že Erich přiznává více problémů v chování, větší nespokojenost $s$ vlastním zjevem a vlastnostmi a více potíží s vrstevníky, než odpovídá průměru. Naopak nejvyšší sebedůvěru Erich vnímá v oblasti Nepodléhání úzkosti (FRE) a v oblasti Intelektové a školní postavení (INT). To znamená, že Erich jednak odmítá, že by pocit’oval smutek, nervozitu a měl nepř́ijemné nálady, zároveň ukazuje na uvědomování si vlastních intelektových schopností a na důvěru ve vlastní schopnosti při plnění školních povinností. Navíc, jak uvádí Obereignerů et al. (2015), jedinci, kteří dosahují nadprůměrných skóre v subškále Nepodléhání úzkosti (FRE), což je i případ Ericha, jsou zpravidla zároveň relativně spokojeni se svým vzhledem, osobnostními vlastnostmi, ale i sociálním fungováním. Jedinci dosahující nadprůměrných hodnot v subškále Intelektové a školní postavení (INT) nejen důvěřují svým intelektovým schopnostem, ale zároveň se cítí jako dobře vychovaní a schopní ve škole udržovat pozornost. Celkově lze tedy předpokládat, že má Erich dobrou úroveň sebeúcty, i když nedosahuje ve všech subškálách vyrovnaných hodnot.

Erichovy výsledky jsou kompatibilní s některými výroky absolventů domácího vzdělávání, kteří se účastnili ohniskových skupin. Ti většinou uváděli, že po přechodu do standardní školy se cítili nadprůměrní z hlediska intelektových schopností, doslova se jedna z účastnic vyjádřila: „... proč bych tam měla chodit, když už to umím? Měla jsem opravdu problém sedět ve škole, když to vlastně nepotřebuji." (Klára, ohnisková skupina, 2017). Zároveň Klára později v rozhovoru přiznala, že ji potěšilo, když při přechodu do školy 
nevstupovala do již zformovaného kolektivu - její obavy z nezapadnutí je možné interpretovat jako nejistotu v oblasti přizpůsobivosti, podobně jako je tomu u Ericha.

Tabulka 6

Průměry Hrubých skóre sebepojetí (TOT, BEH, INT, PHY, FRE, POP, HAP) absolventů $D V$

\begin{tabular}{lccccccc}
\hline Přezdívka & TOT & BEH & INT & PHY & FRE & POP & HAP \\
\hline Erich & 48 & 42 & 57 & 40 & 59 & 42 & 47 \\
Jan & 57 & 56 & 57 & 54 & 59 & 49 & 51 \\
Jolana & 35 & 42 & 54 & 40 & 28 & 42 & 26 \\
Marek & 32 & 39 & 36 & 34 & 36 & 45 & 26 \\
Šimon & 59 & 62 & 62 & 51 & 62 & 49 & 55 \\
Václav & 35 & 32 & 30 & 40 & 51 & 20 & 43 \\
\hline
\end{tabular}

Pozn.: Data z vlastního šetření.

\section{Testové profily absolventů DV}

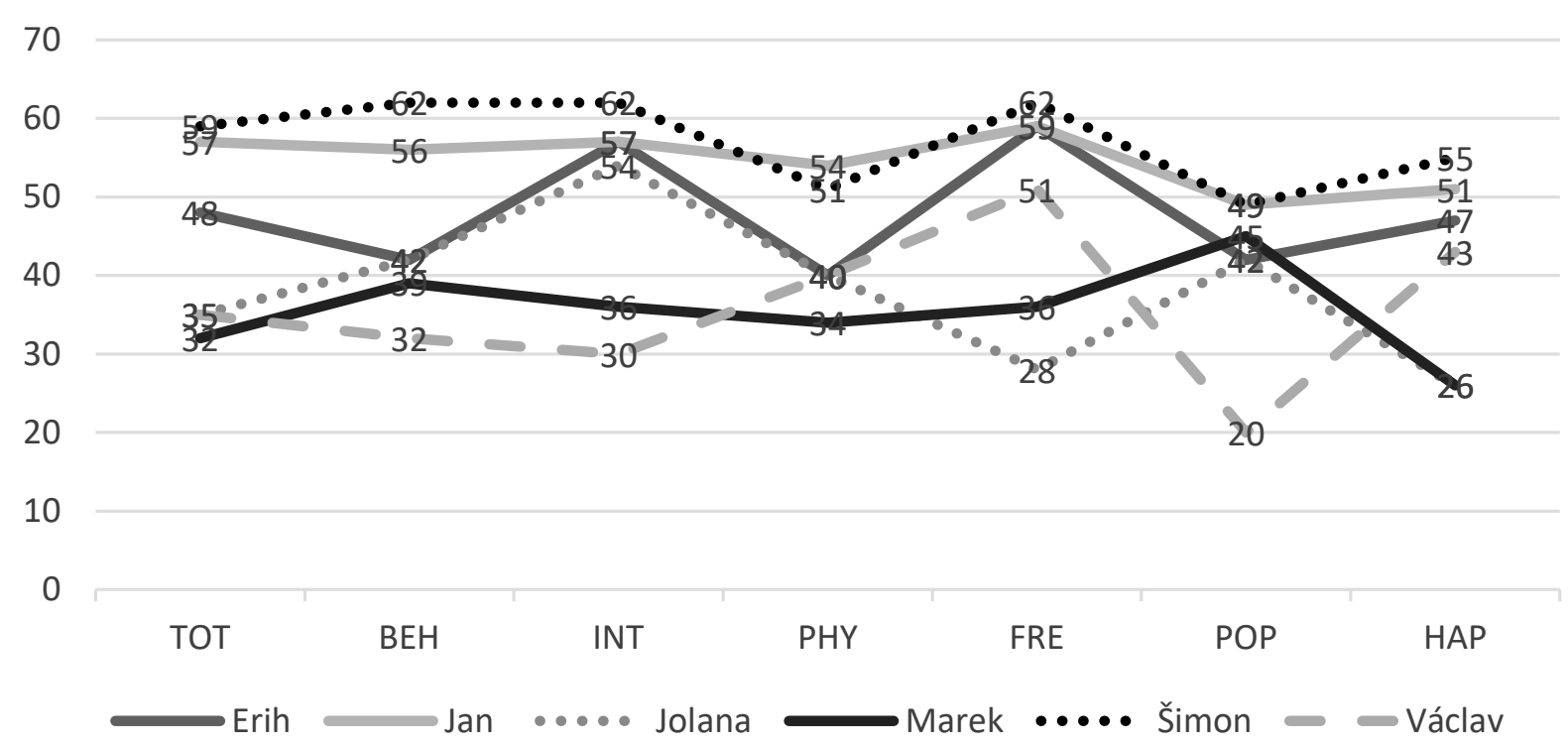

Obrázek 1. Testové profily absolventů DV. 
Jan

Jan patři do skupiny žáků, jejichž Celkové skóre (TOT) se nachází v pásmu vyššího průměru. Obdobně jako u Ericha lze tedy i u Jana předpokládat, že má dobrou úroveň sebeúcty. Jan má navíc velmi vyvážené sebehodnocení ve všech sledovaných oblastech: Přizpůsobivost (BEH), Intelektové a školní postavení (INT), Fyzický zjev a vlastnosti (PHY), Nepodléhání úzkosti (FRE), Popularita (POP), Štěstí a spokojenost (HAP). Ve třech subškálách, Přizpůsobivost (BEH), Intelektové a školní postavení (INT) a Nepodléhání úzkosti (FRE), se hodnoty, kterých Jan dosáhl, nacházejí v pásmu nadprůměru. Jan se cítí dobře vychovaný a schopný dodržovat stanovená pravidla, viz vysoká hodnota BEH. Zároveň odmítá, že by pocitoval př́lišný smutek, nervozitu nebo měl nepř́ijemné nálady, viz vysoká hodnota FRE. V neposlední řadě si je Jan vědom svých intelektových schopností a úspěchu při plnění školních dovedností, viz vysoká hodnota u subškály INT. Nejnižší skóre Jan získal v subškále Popularita, nicméně toto skóre se nachází v pásmu průměru, což svědčí o převažující spokojenosti se sociálním fungováním.

Podobně jako v předchozím př́ípadě, i u Jana lze s odkazem na získaná kvalitativní data poukázat na opakovaně zjištované charakteristiky absolventa DV, především důvěru ve vlastní intelektové schopnosti. Určitá část absolventů DV zařazených v kvalitativní studii nepocitovala žádné napětí po přechodu do školy. U většiny z nich se ovšem objevovaly náznaky určitého nesouladu se spolužáky, často vágně vyjádřeny podobně jako v následujícím úryvku: „... ano, samozřejmě jsem měla nějaké problémy a konflikty se spolužáky, ale to bylo dané tím, že jsem moc extrovertní..." (Denisa, rozhovor, 2016).

\section{Jolana}

Celkové skóre (TOT) Jolany se nachází v pásmu podprůměru. Ne vždy se však jedinec hodnotí negativně ve všech sledovaných oblastech, respektive subškálách. Toto je i př́klad Jolany. Jolana se ve čtyřech ze šesti subškál, Přizpůsobivost (BEH), Intelektové a školní postavení (INT), Fyzický zjev a vlastnosti (PHY) a Popularita (POP), nachází v pásmu průměru či nižšího průměru. Nejvíce Jolana důvěřuje svým intelektovým dovednostem a schopnosti zvládat školní povinnosti. Nejnižších hodnot nicméně Jolana dosahuje ve škálách Nepodléhání úzkosti (FRE) a Štěstí a spokojenost (HAP). Jolana získala body ve škále HAP pouze ve dvou položkách: Mám štěstí a Dobře vycházím s ostatními. Důvodem negativních pocitů, které Jolana prožívá, není pravděpodobně vyčlenění z kolektivu, protože samotná Jolana udává, že se 
z kolektivu vyčleněná necítí, ale nespokojenost sama se sebou, speciálně pak se svým vzhledem. Jolana se necítí spokojená s tím, jaká je, chtěla by být jiná, často se bojí a snadno se rozpláče. Z výše uvedeného je zřejmé, že Jolana prožívá řadu negativních emocí, dokonce se domnívá, jako jediný absolvent DV v našem souboru, že není dobrým člověkem. Navzdory tomu na otázku Nesnáším školu odpověděla záporně. Zdá se tedy, že samotná škola není zdrojem jejích největších prožívaných obtíží. Výsledky naznačují v daném případě vhodnost dále zkoumat Jolaninu situaci a souvislosti jejích negativních pocitů, na místě může být i volba vhodné intervence. Jak naznačují autoři dotazníku (Obereignerů et al., 2015), nízké hodnoty jako u Jolany již mohou poukazovat na emoční problémy závažnějšího rázu.

\section{Marek}

Celkové skóre (TOT) se nachází v pásmu podprůměru. Jedná se o skóre typické pro žáky s nízkou úrovni sebepojetí a pochybnostmi o vlastní hodnotě (Obereignerů et al., 2015). Marek dosahuje ve všech subškálách, kromě subškály Popularita (POP), podprůměrných hodnot. Nejnižší skóre dosahuje obdobně jako Jolana v subškále Štěstí a spokojenost (HAP), což může obdobně jako u Jolany indikovat nespokojenost se sebou samým, navíc nízké skóre již může signalizovat vyšší pravděpodobnost výskytu závažnějších problémů v emoční rovině či v chování.

Podobné př́ípady jako Jolana a Marek tvořily v našem kvalitativním výzkumu spíše výjimky. Jednou z nich byla Irma, která sama sebe vnímala sice jako nadanou, ale zároveň plachou až úzkostlivou. Irma při osobním setkání dokonce naznačila, že DV mohlo její emoční vypětí ještě zhoršovat, nebot' ve škole se kvưli DV cítila „jiná“ (terénní poznámky, 2016).

\section{Šimon}

Šimonovo Celkové skóre (TOT) se nachází v pásmu vyššího průměru. Šimon dosáhl nejvyšší hodnoty Celkového skóre (TOT) v námi sledované skupině absolventů domácího vzdělávání. Nadprůměrných skóre dosáhl i ve třech ze šesti subškál: Přizpůsobivost (BEH), Intelektové a školní postavení (INT), Nepodléhání úzkosti (FRE), obdobně jako Jan. Šimon se vnímá jako dobře vychovaný, ve škole i doma dodržuje stanovená pravidla, zároveň důvěřuje svým intelektovým schopnostem a dovednostem a schopnosti zvládat školní úkoly a povinnosti. Zároveň odmítá, že by pocitoval smutek, nervozitu či 
měl nepř́ijemné nálady. Průměrné dosažené skóre v subškálách Fyzický zjev a vlastností (PHY), Popularita (POP) a Štěstí a spokojenost (HAP) znamenají, že u Šimona převažuje nad negativním hodnocením vlastního vzhledu a vlastností hodnocení pozitivní, převažuje u něj spokojenost v sociální oblasti a vyváženě hodnotí životní okolnosti. Obdobně jako ostatní absolventi domácího vzdělávání v tomto vzorku Šimon nesouhlasí s tím, že by nesnášel školu.

I řada absolventů, kteří se účastnili kvalitativní části výzkumu, měla ke škole kladný vztah. Dá se říci, že s výjimkou ranního vstávání oceňovali především, že učitelé dokáží rozpoznat a vyzdvihnout jejich schopnosti a domnívali se, že je škola rozvíjí po intelektuální stránce (zúčastněné pozorování, 2017).

\section{Václav}

Václav je jedním ze tří absolventů domácího vzdělávání, kteří v dotazníku PHCSCS2 získali podprůměrné Celkové skóre (TOT), viz tabulka 6. Výsledky $\mathrm{v}$ jednotlivých subškálách se u Václava velmi různí. Rozdíl v počtu bodů mezi subškálou, ve které Václav dosáhl nejvíce bodů (Nepodléhání úzkosti - FRE), a subškálou s nejnižším hodnocením (Popularita - POP) je 31 bodů. Václav udává převažující pozitivní prožívané emoční stavy, o čemž svědčí hodnota 51 dosažená v subškále Nepodléhání úzkosti (FRE). V pásmu nižšího průměru se nachází hodnoty v subškálách: Fyzického zjevu a vlastností (PHY) a Štěstí a spokojenost (HAP). Podprůměrných hodnot dosahuje Václav v subškálách Přizpůsobivost (BEH) a Intelektové a školní postavení (INT), což je znakem toho, že Václav přiznává významné problémy v chování. Podle vlastního přesvědčení je sám zdrojem problémů a má problém dodržovat stanovená pravidla. Jeho nízké skóre v subškále Intelektové a školní postavení (INT) ukazuje na to, že Václav přiznává významné potíže i při plnění školních povinností. Nejnižší skóre Václav získal v subškále Popularita (POP). Nízkých skóre v POP vykazují jedinci, kteří se necítí dobře v oblasti sociálního fungování (Obereignerů et al., 2015), nicméně nízké hodnoty v POP mohou souviset také s nedostatky v chování či s výukovými problémy. Obereignerů a kol. (2015) zmiňují, že žáci s výukovými problémy, jako je tomu u Václava, mohou pocitovat odmítání ze strany svých spolužáků. U Václava by bylo vhodné dále zjištovat např́iklad jakých studijních výsledků dosahuje, zda se subjektivně vnímané těžkosti odráží i v hodnocení, nebo jsou spíš odrazem vysokých nároků, které sám na sebe klade. 


\section{Diskuse a závěr}

Cílem této pilotní studie bylo vnést více světla do procesu druhotné socializace doma vzdělávaných dětí a otevřít prostor pro další výzkumy v dané oblasti. Pro identifikaci sebepojetí dětí se zkušeností s domácím vzděláváním byl využit Dotazník sebepojetí dětí Piers-Harris 2, který umožňuje srovnání dosažených výsledků se standardizačním vzorkem. Navíc bylo zjištováno i sebepojetí spolužáků dětí se zkušeností s domácím vzděláváním jako svým způsobem kontrolní skupiny. Studie ukazuje, že identifikované rozdíly ve výsledcích dětí se zkušeností s domácím vzděláváním a jejich spolužáků byly velmi malé a statisticky nevýznamné, což je ale dáno i velikostí porovnávaných souborů. Výsledky neidentifikují významný dopad domácího vzdělávání na sebepojetí takto vzdělávaných dětí. Oproti studiím, které prokazují významně lepší výsledky doma vzdělávaných dětí (viz například Taylor, 1986, 1992), a na druhé straně oproti názorům obávajícím se o to, zda děti v domácím vzdělávání prospívají, naše výsledky spolu s některými poznatky z kvalitativní studie naznačují spíš individuální variabilitu vlivu domácího vzdělávání na sebepojetí dítěte; v celkovém vzorku je tento vliv neutrální, není vychýlen ani negativním, ani pozitivním směrem.

Námi zjištěné výsledky nicméně není možné žádným způsobem generalizovat, protože si uvědomujeme komplexnost celé problematiky. Mohou však rozšírit současné poznání a podnítit další výzkumnou činnost v této oblasti nebo posloužit dalším studiím jako srovnání. V každém případě se ukazuje, že použití dotazníku sebepojetí Piers-Harris 2 je užitečným nástrojem, který lze využít pro studium domácího vzdělávání a jeho dopadů, nicméně do budoucna je nezbytné tento nástroj používat v souvislosti s dalšími nástroji a výzkumnými postupy (zejména individuálními rozhovory, sociometrií aj.).

Za hlavní přínos této pilotní studie považujeme obrácení pozornosti k individualitě vzdělávaného, nikoliv pouze vzdělávajícího, což je $v$ prŕípadě studií zaměřených na domácí vzdělávání převažující přístup (viz například Lois, 2009, 2013). Někteří autoři (viz např́iklad Jones, 2013; Van Schalkwyk \& Bouwer, 2011) upozorňují na potřebu vytvářet prostor, ve kterém by mohly zaznít hlasy nejen vzdělavatelů, ale i samotných žáků vzdělávaných doma. 


\section{Dedikace}

Tento článek vznikl za finanční podpory Grantové agentury České republiky, která podpořila projekt s názvem: Domácí vzdělávání - fakta, analýzy, diagnostika, registrační číslo projektu GA: 16-17708S.

\section{Literatura}

Blatný, M. (2010). Sebepojetí z pohledu sociálně-kognitivní psychologie. In M. Blatný (Ed.), Psychologie osobnosti. Hlavní témata, současné př́stupy. Praha: Grada.

Hájková, E. (2017). Školy v Březové: Bohemistika, lingvistika a lingvodidaktika v historickém pohledu školy. Didaktické studie, Praha: Pedagogická fakulta UK, 9(1), 41-48.

Hána, D. (2017). Systémy domácího vzdělávání v Evropě. Informace CGS, 36(1), 20-30.

Jančaříková, K., \& Jančařík, A. (2017). Teaching aids and work with models in e-learning environments. The Electronic Journal of e-Learning (EJEL), 15(3), 244-258.

Jones, T. (2013). Through the lens of home-educated children: Engagement in education. Educational Psychology in Practice, 29(2), 107-121.

Kašparová, I. (2015a). Homeschooling, freedom and control in Czech education. Global dialogue. Magazine of International Sociological Association, 5(3), 31-32.

Kašparová, I. (2015b). The right to be included: Homeschoolers combat the structural discrimination embodied in their lawful protection in the Czech Republic. International Electronic Journal of Elementary Education, 8(1), 624-642.

Kašparová, I. (2017). Domácí vzdělávání jako výraz kulturního kreativismu. Sociologický časopis / Czech Sociological Review, 53(1), 79-100.

Kenny, M. C., \& Vazquez, A. L. (2017). Piers-Harris children's self-concept scale. In V. Zeigler-Hill \& T. K. Shackelford (Eds.), Encyclopedia of personality and individual differences (s. 1-4). Springer International Publishing.

Kostelecká, Y. (2003). Domácí vzdělávání (Disertační práce). Praha: Univerzita Karlova Pedagogická fakulta.

Kostelecká, Y. (2010). Home education in the post-communist countries: Case study of the Czech Republic. International Electronic Journal of Elementary Education, 3(1), 29-44.

Kostelecká, Y. (2012). The legal status of home education in post-communist countries of Central Europe. International Review of Education, 58(4), 445-463.

Kostelecká, Y. (2014a). Domácí vzdělávání a legislativa: studie postkomunistických států střední Evropy. Orbis scholae, 8(1), 9-26.

Kostelecká, Y. (2014b). Doma, nebo ve škole? Studia peadagogica, 19(1), 65-81.

Kostelecká, Y. (2017a). Out of school education in the Czech Republic. Conference proceedings: The Future of Education. Padova: Liberl Universitaria.

Kostelecká, Y. (2017b). Home education experience in selected post-ommunist countries. In M. Gaither (Ed.), The Wiley handbook of home education (s. 422-445). Malden: John Wiley.

Kostelecká, Y., Zimčík, L., Jančařík, A., \& Jančaříková, K. (2016). Distance learning and the home schooling in the Czech Republic. In Proceedings of the European Conference on e-Learning (s. 364-372). Reading: Academic and Conferences Publishing International Limited. 
Lois, J. (2009). Emotionally layered accounts: Homeschoolers' justifications for maternal deviance. Deviant Behavior, 30, 201-234.

Lois, J. (2013). Home is where the school is: The logic of homeschooling and the emotional labor of mothering. New York: New York University Press.

Medlin, R. G. (2013). Homeschooling and the question of socialization revisited. Peabody Journal of Education, 88(3), 284-297.

Mertin, V. (2003). Pedagogicko-psychologické aspekty individuálního vzdělávání. Pedagogika, 53(4), 405-417.

Obereignerů R. et al. (2015). Dotazník sebepojetí dètí a adolescentů Piers-Harris 2. Jak vnímám sám/sama sebe. Praha: Hogrefe - Testcentrum.

Piers, E. V. (1984). Piers-Harris children's self-concept scale (Rev. manual). Los Angeles: Western Psychological Services.

Piers, E. V. (1994). Revised manual for the Piers-Harris children's self-concept scale. Los Angeles: Western Psychological Services.

Piers, E. V., \& Herzberg, D. (2002). Piers-Harris 2: Piers-Harris children's self-concept scale, 2nd edition manual. Los Angeles: Western Psychological Services.

Pražáková, D. (2012). Matematika v domácím vzdělávání: charakteristiky vzdělávacího stylu rodin (Disertační práce). Praha: Univerzita Karlova, Pedagogická fakulta.

Ray, B. D. (2013). Homeschooling associated with beneficial learner and societal outcomes but educators do not promote it. Peabody Journal of Education, 88(3), 324-341.

Romanowski, M. H., \& Pham, X. N. (2006). Revisiting the common myths about homeschooling. The Clearing House: A Journal of Educational Strategies, Issues and Ideas, 79(3), 25-129.

Štech, S. (2003). Škola, nebo domácí vzdělávání? Teoretická komplikace jedné praktické otázky. Pedagogika, 53(4), 418-436.

Taylor, J. W. (1986). Self-concept in home-schooling children (Disertační práce). Dostupné $\mathrm{z}$ https://digitalcommons.andrews.edu/dissertations/726.

Taylor, J. W. (1992). The self-concept of home schoolers a nationwide study. Journal of Research on Christian Education, 1(1), 23-34.

Van Schalkwyk, L., \& Bouwer, C. (2011). Homeschooling: Heeding the voices of learners. Education as Change, 15(2), 179-190.

\title{
Self-concept of classmates with and without home education experience
}

\begin{abstract}
The study is the first research focused on issues of self-concept of children with home education experience. Self-concept is an important topic which has not received much attention in our country. The aim of the study is to find out how those children perceive themselves and to compare their results with their classmates who have not had this specific experience. The first part of the paper is concentrated on theoretical background, self-concept and methodology of the research; the second one presents results of the pilot research. One of the main benefits is that the study diverts attention from the perspective of the teacher (which was the dominating
\end{abstract}


approach so far) to the perspective of the individuality of the student; the second one is that it verifies Piers-Harris Children's Self-Concept Scale as proper instrument for implementation similar focused researches.

Key words: home education, self-concept, social development, emotional development, adaptation

\section{Autoři}

Mgr. Yvona Kostelecká, Ph.D., Univerzita Karlova v Praze, Pedagogická fakulta, Ústav profesního rozvoje pracovníků ve školství, Magdalény Rettigové 4, 11639 Praha 1, e-mail: yvona.kostelecka@pedf.cuni.cz

Mgr. Kateřina Machovcová, Ph.D., Univerzita Karlova v Praze, Pedagogická fakulta, Ústav profesního rozvoje pracovníků ve školství, Magdalény Rettigové 4, 11639 Praha 1, e-mail: katerina.machovcova@pedf.cuni.cz

PhDr. Andrea Beláňová, Ph.D., Univerzita Karlova v Praze, Pedagogická fakulta, Ústav profesního rozvoje pracovníků ve školství, Magdalény Rettigové 4, 11639 Praha 1, e-mail: andrea.belanova@pedf.cuni.cz

Bc. Romana Štambergová, Univerzita Karlova v Praze, Pedagogická fakulta, Magdalény Rettigové 4, 11639 Praha 1, e-mail: stambergova@gmail.com 